\title{
Review on Health Benefits of Spearmint (Mentha spicata L.) and Its Inter-cropping Advantage with Maize (Zea mays L.)
}

\author{
Desta Abayechaw ${ }^{1 *}$ and Tarekegn Yoseph ${ }^{2}$ \\ ${ }^{1}$ Wondogenet Agricultural Research Center, Ethiopian Institute of Agricultural Research, Ethiopia. \\ ${ }^{2}$ School of Plant and Horticultural Sciences, College of Agriculture, Hawassa University, Ethiopia.
}

*Corresponding author: Desta Abayechaw, Wondogenet Agricultural Research Center, Ethiopian Institute of Agricultural Research, Ethiopia.

\section{Received date: July 19, 2021; Accepted date: August 05, 2021; Published date: August 16, 2021}

Citation: Desta Abayechaw and Tarekegn Yoseph. (2021). Review on Health Benefits of Spearmint (Mentha spicata L.) and Its Inter-cropping Advantage with Maize (Zea mays L.). J. Nutrition and Food Processing, 4(6); DOI:10.31579/2637-8914/060

Copyright: ( 2021 , Desta Abayechaw. This is an open access article distributed under the Creative Commons Attribution License, which permits unrestricted use, distribution, and reproduction in any medium, provided the original work is properly cited.

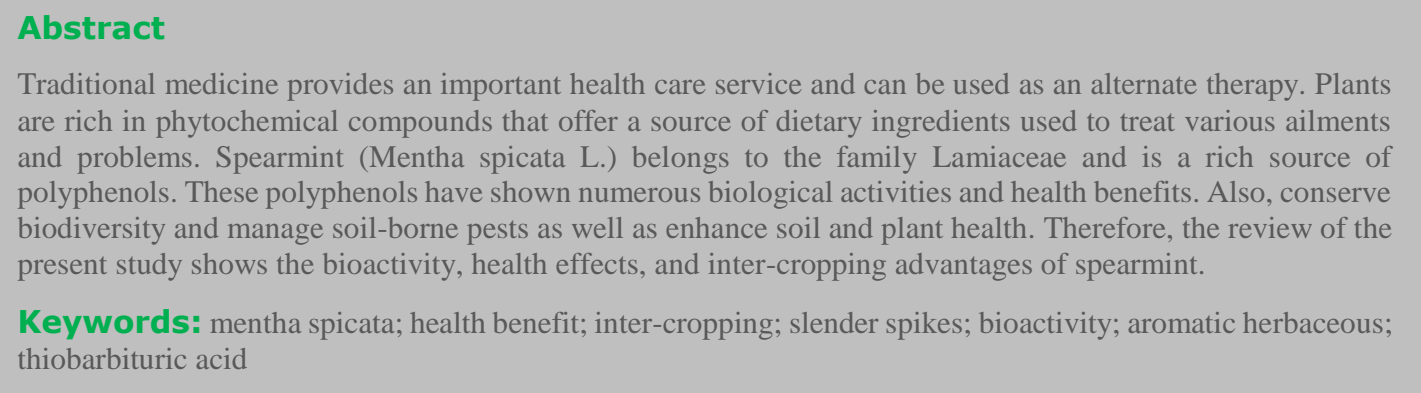

\section{Introduction}

Spearmint (Mentha spicata L.), is an aromatic herbaceous, rhizomatous, and perennial herb belonging to the Lamiaceae family [4]. The plants of this family are a rich source of polyphenols and thus possessing strong antioxidant properties [20,8]. Spearmint is indigenous to northern England [46] and is cultivated in areas with a climate ranging from tropical to temperate, such as America, Europe, China, South Africa, and $[20,39]$. Nowadays, spearmint is widely grown throughout all regions of the world [15]. Spearmint is also known as brown mint, garden mint, lady's mint, and sage of Bethlehem [48]. Spearmint is a creeping rhizomatous and herbs $[24,28]$. The leaves are broad and sharply serrate. The trademark of the mint family is the square-shaped stem [11]. Spearmint produces rightly and long pink or white flowers in slender spikes. Spearmint leaves possess a characteristic aromatic odor and pungent taste. However, in contrast to peppermint and Japanese mint, the cooling after-effect is absent in spearmint $[11,24]$.

Mentha plants are one of the most popular herbs that have been used for their medicinal and aromatherapeutic properties since ancient times. Spearmint has a long tradition of medicinal use. It was taken as a tea to treat general digestive problems. Spearmint is widely used in a commercially manufactured product, cooking, and medicine for its aromatic and flavorsome qualities. There are numerous health benefits of spearmint essential oil such as it can reduce fever, provide relief from depression and asthma [12]. Mint was originally used as a medicinal herb to treat stomach ache and chest pains, and it is commonly used in the form of tea as a home remedy to help alleviate stomach pain. During the middle Ages, powdered mint leaves were used to whiten teeth. Its tea is a strong diuretic. Also aids digestion, in a way that it breaks down the fats. In recent years, it has been often recommended for treating obesity. It has been well known that spearmint essential oils have antimicrobial and antioxidant effects [44]. Also, a common need is the availability of natural extracts with a pleasant taste or smell combined with a preservative action, aimed to avoid lipid deterioration, oxidation, and spoilage by microorganisms [49]. It is essential oil did not show any evidence of mutagenicity in the Ames test [1]. Spearmint has also been described as having excellent antioxidant activity comparable to BHT [30]. Due to both its antioxidant activity and its common use to season lamb in South Asian cuisine, it has been studied as an additive to radiation-processed lamb meat and was found effective in delaying oxidation of fats and reducing the formation of harmful substances, which can be detected using thiobarbituric acid as a reagent [30]. Spearmint has been studied for antifungal activity; it is essential oil was found to have some antifungal activity, although less than oregano [1].

Spearmint is mainly consumed and used in Mediterranean, European, and Indian cultures as a flavor ingredient in tea, beverage, and cooked meat preparations $[38,56]$. Recently, M. spicata has become a subject of scientific interest because of other potential uses of its essential oil and extracts, for the most part, as antimicrobial and antioxidant agents [40].

In addition to the health benefit of spearmint as explained by [6] intercropping spearmint with maize at a $42 \mathrm{~cm}$ inter-row spacing of 
spearmint followed by $36 \mathrm{~cm}$ inter-row spacing is biologically efficient, economically feasible, and more profitable and provides opportunities for the producers than planting alone. However, recent scientific studies showed spearmint consumption its associated health benefits and advantages in the cropping system especially with maize which needs scientific evidence in an advance and through intensive research. With these in mind, the main aim of this review was to reports works done with a wide-ranging overview of the health benefits of spearmint and its intercropping advantages with maize.

\section{Major Chemical Compounds of Spearmint}

The constituents found in spearmint are shown in (Table 1) below.

\begin{tabular}{|l|l|l|l|}
\hline Compound & Percentage $(\mathbf{\%})$ & Compound & Percentage $(\mathbf{\% )}$ \\
\hline$\beta$ - myrcene & 0.25 & Trans-carveol & 0.30 \\
\hline Limonene & 11.50 & Carvone & 78.76 \\
\hline$\Gamma$-terpinene & 0.16 & Dihydrocarvyl acetate & 0.57 \\
\hline Menthone & 1.01 & L-carveol & 0.32 \\
\hline Menthol & 1.00 & $\beta$ - bourbonene & 1.23 \\
\hline Terpinen-4-ol & 0.99 & Trans-caryophyllene & 1.04 \\
\hline Q-terpinol & 0.31 & $\gamma$-amorphene & 0.21 \\
\hline Dihydrocarveol & 0.22 & a-amorphene & 0.16 \\
\hline Cis-dihydrocarveol & 1.43 & Other compounds & 0.11 \\
\hline Dihydrocarvone & 0.43 & Total & $\mathbf{1 0 0 . 0 0}$ \\
\hline
\end{tabular}

(Adapted from Shahbazi, 2015)

Table 1. Result of MS essential oil analysis by gas chromatography-mass spectrometry

The main flavor compounds present in spearmint are limonene, dihydro carvone, dihydrocarveol carveol, and carvone $[38,56]$. The most abundant compound in spearmint oil is R (-) carvone, which gives spearmint its distinctive smell. Spearmint oil also contains significant amounts of limonene, dihydro carvone, and 1,8-cineol [25]. Spearmint has a flavor and pungent taste due to the high content of essential oils like carvone [47]. Carvone, a phenolic compound, is the main constituent found in spearmint oil, followed by limonene [20,28]. Carvone is reported to be potential in inhibiting bacterial growth, as well as to act as fungicide and insect repellent. Carvone also reversibly suppresses the sprouting in stored potatoes or flower bulbs.

Carvone renders the characteristic smell of spearmint. The smell is smooth and near analogous to fennel oil. However, (S)-carvone and (R)carvone contribute to the odor of spearmint and caraway seeds respectively. Both are enantiomers of biological material but elicit a different response. Also, S-carvone possesses high antioxidant activity [11].

\section{Bioactivity}

Phenolic compounds extracted from Mentha have various applications in the food and pharmaceutical industries, including antioxidant properties due to the presence of phenolic compounds such as caffeic acid, eugenol, rosmarinic acid, and $\alpha$-tocopherol [2]. The main bioactive compounds in spearmint oil are phenolic compounds, essential oils, and long-chain hydrocarbons. It is reported that spearmint possesses antioxidant activity [9] on account of the presence of phenolic acids, flavonoids, carvone, and ascorbic acid in leaves. According to [51] spearmint can become an alternate form for synthetic antioxidants that bring harmful effects. The biological activities of spearmint also include anti-inflammatory, antimicrobial, and sedative [31]. The good antimicrobial activity is attributed to the high concentration of carvone [51]. Besides, spearmint is carminative, antispasmodic, and diuretic [57].

The contents of phenolic compounds in spearmint oil are $8.9 \mathrm{mg} / 100 \mathrm{~g}$ for caffeic acid, $1344 \mathrm{mg} / 100 \mathrm{~g}$ for rosmarinic acid, and $16.8 \mathrm{mg} / 100 \mathrm{~g}$ for luteolin [62]. Many volatile compounds have been identified in spearmint including flavonoid, thymonin, carvone, and limonene [3]. Reported that extracted phenolic compounds from spearmint have been used for medical purposes.

The major extracted phenolic compounds from Mentha aquatica L. are luteolin-7-O-glucoside, eriocitrin, and rosmarinic acid, whereas hesperidinin, luteolin-7-O-glucoside, eriocitrin, and rosmarinic acid are the major phenolic compounds in Mentha piperita L. $[9,17,34,41,60]$ reported that rosmarinic acid is the predominant phenolic identified in different species of Mentha.

\section{The Excellent Benefits of Spearmint:}

Both fresh and dried spearmint plants are widely used in a variety of applications [37]. Since ancient times, both western and eastern cultures have been practiced spearmint as medical and aromatic plants [44]. In terms of biological uses, spearmint acts as insecticides [49], antispasmodics, and anti-platelets [58]. Moreover, spearmint is used as antimicrobial [55] and antioxidant agents [40].

In terms of medicinal benefits, spearmint is considered as an herbal medicine in folkloric remedies for treating colds and flu, respiratory tract problems, gastralgia, hemorrhoids, and stomachache $[7,57,59]$. Spearmint is extracted in the form of oil and is regularly used in medicine [7] states that spearmint leaves are generally taken as a tea in which its carminative properties can help to treat digestive disorders, fever, and minor ailments [46]. Furthermore, spearmint has broadly been applied to treat various illnesses. For instance, nausea, vomiting, and gastrointestinal disorders $[26,36]$. Also, spearmint flavonoids, thymonin, caffeic acid, rosmaric acid, carvone, and limonene, have been used for medical purposes to address such issues as smooth muscle spasms, increase blood circulation, relieve pain, antiseptic, morning sickness, nausea, menstrual cramps, flatulence, flu, and vomiting [3]. Recently, phenolic compounds in mint have been investigated to repair DNA damage in cancer. Non-volatile components of Mentha species have beneficial effects in human health due to antimicrobial, antioxidant, anti-inflammatory, and antiallergic properties $[9,19,28,41,53,56]$.

Golden benefits of spearmint according to [45] consumption of a proprietary spearmint extract (PSE) can sustainably improve cognitive 
performance in young, healthy adults. Many published works of literature support that PSE can improve aspects of attention [42]. Consumption of PSE has been shown to improve attention and concentration when administered both acutely and chronically for 30 days in an open-label trial of older individuals with self-reported memory impairment [42]. Moreover, 3 small-scale studies in healthy men and women between the ages of 18 and 50 found trends for improvements in objective measures of attention as well as subjective reporting of increased feelings of alertness after acute supplementation with PSE [42]. In addition to the existing human clinical data, the polyphenol molecules contained in PSE have been shown to increase neurotransmitter levels in the brain related to attention $[13,61]$. Specifically, the polyphenols rosmarinic acid and salvianolic acid B have both been shown to inhibit the enzyme that breaks down acetylcholine in the brain [13,61]. In an animal model, rosmarinic acid has been shown to increase levels of acetylcholine in the brain following acute administration [13]. Although the role of acetylcholine in learning and memory has been known for some time, more recent studies have revealed the additional function of acetylcholine for attention in both human and animal studies [33]. In the current study, daily supplementation with spearmint led to an $11 \%$ increase in sustained attention performance. So, sustained attention is an essential component of daily life and refers to the capacity to maintain focus on a specific item or task over an extended period [50]. (Table 2)

\begin{tabular}{|l|l|l|}
\hline \multicolumn{1}{|c|}{ Parameter } & Mean (SEM) & P-value \\
\hline Memory & $3.7(0.2)$ & 0.500 \\
\hline Attention & $3.5(0.2)$ & 0.125 \\
\hline Speed of thinking & $3.4(0.3)$ & 0.125 \\
\hline Average score & $3.5(0.2)$ & $\mathbf{0 . 0 6 3}$ \\
\hline
\end{tabular}

Abbreviations: SEM, standard error of the mean.

Table 2. Subject Global Impression (SGI) scale of cognition questionnaire scores at the end of treatment in response to spearmint supplementation [29].

The SGI questionnaire was administered at the end of the 30-day treatment and subjects were asked to compare their current condition to their condition before inclusion in the study. Scores were coded as: $1=$ very much improved, $2=$ much improved, $3=$ minimally improved, $4=$ no change, $5=$ minimally worse, $6=$ much worse, $7=$ very much worse.

P-values were calculated from Wilcoxon sign rank test, testing the difference from 4 (no change; $n=10$ ) at the end of treatment in the modified intention-to-treat sample.

According to [35] aqueous spearmint extract, containing higher rosmarinic acid content relative to extracts from typical commercial lines, was well-tolerated and bioavailable in older subjects (50-70 years) with self-reported memory impairment. In addition, the aqueous spearmint extract may have implications in cognitive health and warrant further investigation.

Spearmint is commonly used as a domestic herbal remedy. A tea made from the leaves has traditionally been used in the treatment of fevers, headaches, digestive disorders, and various minor ailments [14]. The herb is antiemetic, antispasmodic, carminative, diuretic, restorative, stimulant, and stomachic $[10,16,39]$. The leaves should be harvested at the time of flower initiation of the plant and can be dried for later use [16]. The essential oil of the plant is antiseptic, though it is toxic in large doses [14]. The essential oil and the aerial stems are often used in folk remedies for cancer and a poultice prepared from the leaves (macerated leaves) is said to remedy tumors [10].

Phenolic compounds are among the bioactive food components with potential health benefits [21]. Dietary phenolics are well documented to decrease the risk of chronic diseases (e.g., type 2 diabetes, cardiovascular diseases, gastrointestinal diseases, and some cancers), and to have antiviral, antibacterial, antifungal, laxative, and anti-inflammatory activities [21].

Another benefit in terms of food uses, spearmint is used in food, confectionery, and chewing gum industries [7,26,37]. Spearmint contributes to food preservation [52] and imparts food taste and aroma [26]. Spearmint is used in Iran as a flavoring agent in food products such as cheese and doogh [54]. Besides, spearmint is added in Indian and Italian cuisine, either in fresh or dried form, to fish and shellfish plates before or after cooking [32,57]. Owing to the antioxidant, antiradical and chelating properties it possesses, the incorporation of spearmint in food can help to maintain the equilibrium of redox status in an organism as well as to improve safety and effect on human wellbeing [20]. Spearmint has been used broadly in cosmetics and soap [7,26,37] as well as toothpaste, breath freshener, an antiseptic mouth rinse [26,36].

\section{Spearmint Intercropping Advantages with Maize}

Many studies have emphasized the advantage of medicinal plants in intercropping systems, such as cassava/okra, Okra with chili pepper, saffron with chamomile, and spearmint with maize, were also reported. Also, to conserve the biodiversity, presence of medicinal plants in intercropping will also enhance their yield quantity. For instance, intercropping peppermint plants with soybean produced a significantly higher amount of essential oil when compared to monoculture plants, and the oil yield increased by 50\%. Also, intercropping of spearmint with maize has advantages on weed suppression. Spearmint increased soil organic $\mathrm{C}$ and $\mathrm{N}$ by $32 \%$ and $47 \%$ within 2 years, respectively.

According to [6] in intercropping of maize with spearmint there was no significant $(p>0.05)$ yield variation in the two consecutive two cropping years. Similarly, the overall pooled mean showed there was no significant variation between intercropped and sole treatments and between each intercropped treatment. Even if no significant variation was observed in the pooled mean, the highest yield was recorded at $42 \mathrm{~cm}$ inter row spacing of spearmint intercropped with maize which was similar to the individual harvesting seasons. This was possibly due to no shading effect of spearmint on maize and less competitiveness for the resources from the associated crops. Similar finding was reported by Prasad and Brook (2004) who observed that maize yield was not significantly influenced by soybean in maize- soybean intercropping systems under various densities of maize. (Figure 1) 


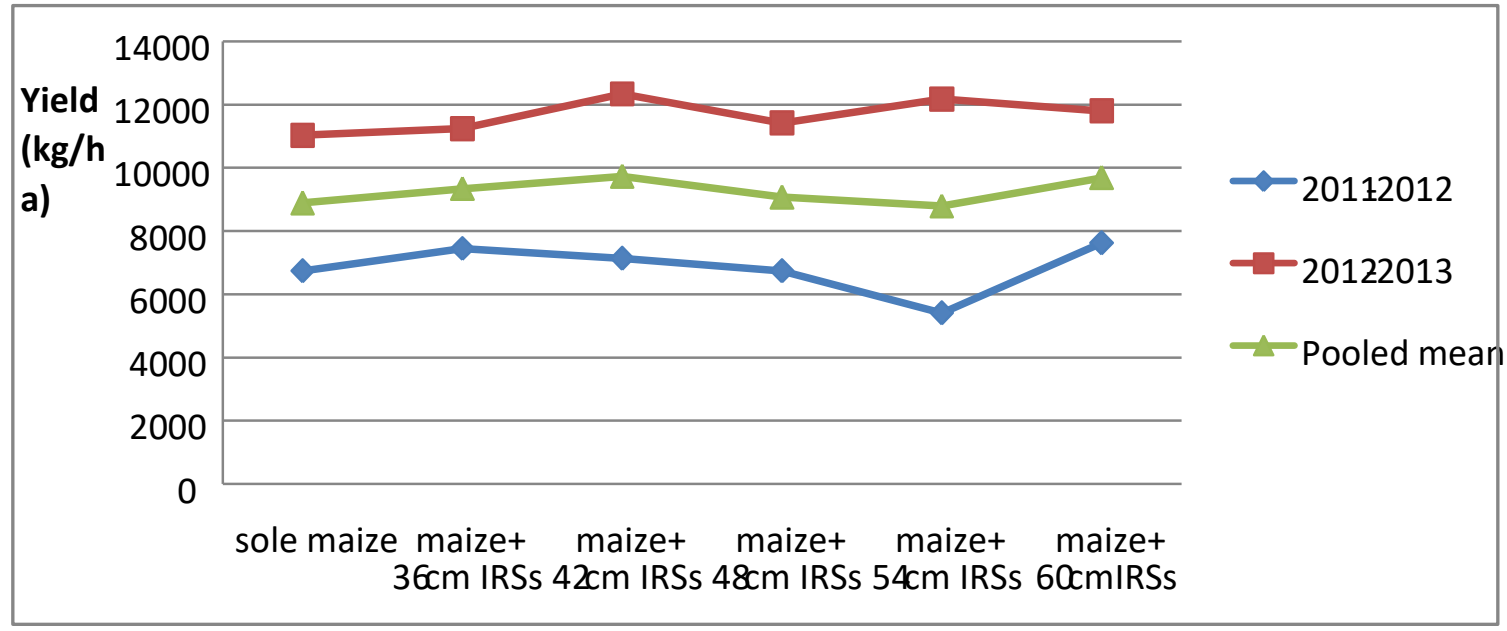

Figure 1. Influence of maize-spearmint intercropping on grain yield of maize

The benefits of spearmint in an intercropping system suggest that mint may benefit the management of soil-borne pests as well as enhance soil and plant health. Soil health is the capacity of a soil to function within its ecosystem boundaries to sustain biological productivity, maintain environmental quality, and promote plant and animal health [60]. (figure 2)

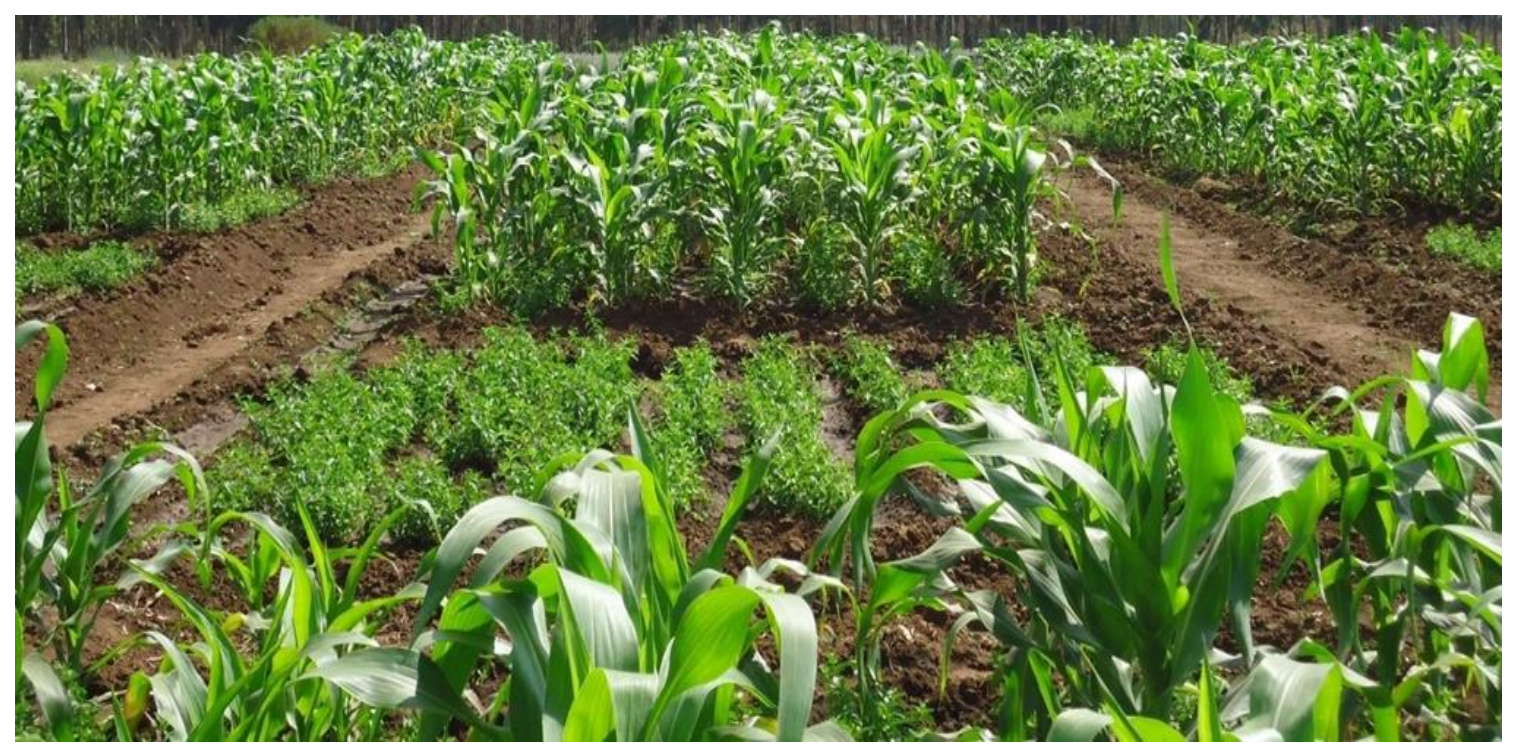

Sources: Lulie et al. (2014)

Figure 2. Mint plants in the field

\section{Summary and Conclusion}

Spearmint is an aromatic herbaceous, rhizomatous, and perennial herb belonging to the Lamiaceae family. The main flavor compounds present in spearmint are limonene, dihydro carvone, dihydrocarveol carveol, and carvone. Also, the main bioactive compounds in spearmint oil are phenolic compounds, essential oils, and long-chain hydrocarbons. Phenolic compounds in spearmint were exhibited many biological activities. Thus, spearmint has great potential to be used in medical value especially according to Paul consumption of a proprietary spearmint extract can sustainably improve cognitive performance in young, healthy adults and functional foods applications. Spearmint has benefits in the intercropping system by sustaining biological productivity, maintain environmental quality, and promote plant and animal health. But the updated information worldwide about health benefits and its intercropping advantages of spearmint was scanty. So, further studies and advanced researches are needed to enhance its cropping system, properties, and increase its applications.

\section{Acknowledgment}

The first author would like to thanks the instructor Dr. Tarekegn Yoseph for his advice and guidance in the entire scientific paper writing.

\section{References}

1. Adam K, Sivropoulou A, Kokkini S, Lanaras T, and Arsenakis M. (1998). Antifungal Activities of Origanum vulgare subsp. hirtum, Mentha spicata, Lavandula angustifolia, and Salvia fruticosa Essential Oils against Human Pathogenic Fungi. Journal of Agricultural and Food Chemistry 46: 1739-1745. 
2. Al-Sereiti, M.R., Abu-Amer, R.M., and Sen P. (1999). Pharmacology of rosemary (Rosmarinus officials Linn.) and its therapeutic potentials. Indian J. Exp. Bio. 37, 124-130.

3. Alu'datt, M.H., Rababah, T., Alhamad, M.N., Ereifej, K., AlMahasneh, M., Brewer, M.S., and Rawshdeh, M. (2016). Optimization extraction conditions for phenolic compounds, antioxidant and inhibitory activities of the angiotensin-I converting enzyme (ACE), $\alpha$-glucosidase, and $\alpha$-amylase from Mentha spicata L. J. Food Biochem. 40 (3), 335-344.

4. Arzani, A., Zeinali, H, and Razmjo, K. (2007). Iron and magnesium concentrations of mint accessions (Mentha spp.). Plant Physiol. Biochem., 45, 323-329.

5. Asekun OT., Grierson DS., Afolayan AJ. (2007). Effects of drying methods on the quality and quantity of the essential oil of Mentha longifolia L. subsp. Capensis. Food Chem 101: 995998.

6. Belstie Lulie1., Haymanot Getu, and Tesfa Bogale. (2014). Intercropping of maize (Zea mays L.) with Spearmint (Mentha spicata L.) as Supplementary Income Generation at Wondo Genet Agricultural Research Center, South Ethiopia. International Journal of Recent Research in Life Sciences (IJRRLS). pp: 31-43.

7. Bensabah F., Houbairi S., Essahli M., Lamiri A., and Naja, J. (2013). Chemical Composition and Inhibitory Effect of the Essential Oil from Mentha Spicata Irrigated by Wastewater on the Corrosion of Aluminum in 1 Molar Hydrochloric Acid. Port Electro Chimica Acta 31: 195-206.

8. Bimakr M., Rahman RA., Taip FS., Ganjloo A., and Salleh LM. (2011). Comparison of different extraction methods for the extraction of major bioactive flavonoid compounds from spearmint (Mentha spicata L.) leaves. Food Bioprod Process 89: 67-72.

9. Dorman HJ., Koşar M., Kahlos K., Holm Y., and Hiltunen R. (2003). Antioxidant properties and composition of aqueous extracts from Mentha species, hybrids, varieties, and cultivars. J Agr Food Chem 51: 4563-4569.

10. Duke JA., and Ayensu ES. (1985). Medicinal plants of China, Reference Publications, Inc. ISBN 0- 917256-20-4.

11. Elmastaş M., Dermirtas I., Isildak O., and Aboul-Enein HY. (2006). Antioxidant Activity of S-Carvone Isolated from Spearmint (Mentha Spicata L. Fam Lamiaceae). J Liquid Chromate Related Technol 29: 1465-1475

12. El-Moghazy MA. (2008). Chemical inhibition effects of some plant extract on spoilage microorganisms in food. Thesis, Faculty of Agriculture, Ain Shams University, Cairo, Egypt. AM 6(5); 272-279.

13. Fale PL, Madeira PJ, Florencio MH, Ascensao L, and Serralheiro ML. (2011). The function of Plectranthus barbatus herbal tea as neuronal acetylcholinesterase inhibitor. Food Funct; 2:130-136.

14. Foster S., and Duke JA. (1990). A field guide to medicinal plants: Eastern and Central N. America, Houghton Mifflin Co. ISBN 0395467225.

15. Ghderi PGhderi P., Ahmadi R., Balkanyian F., Moridikyia A., and Mahdavi E. (1975). The essential oils.5th printing, D. Van. Nostard Company, Inc. (Princeton, New Jersey), I: 50-83; III: 676-683.

16. GRIEVE. (1984). A modern herbal, Penguin, ISBN 0-14-046440-9.

17. Guedon, D.J., and Pasquier, B.P. (1994). Analysis and distribution of flavonoid glycosides and rosmarinic acid in 40 Mentha x piperita clones. J. Agric. Food Chem. 42 (3), 679-684.

18. Guimarães R, Barreira J, Barros L, Carvalho AM, Ferreira IC. (2011). Effects of oral dosage form and storage period on the antioxidant properties of four species used in traditional herbal medicine. Phytother Res 25: 484-492.

19. Gulluce, M., Sahin, F., Sokmen, M., Ozer, H., Daferera, D., Sokmen, A., Polissiou, M., Adiguzel, A., and Ozkan, H. (2007). Antimicrobial and antioxidant properties of the essential oils and methanol extract from Mentha Longifolia L. Ssp. Longifolia. Food Chem. 103 (4), 1449-1456.

20. Hajlaoui H, Trabelsi N, Noumi E, Snoussi M, Fallah H. (2009). Biological activities of the essential oils and methanol extract of two cultivated mint species (Mentha longifolia and Mentha pulegium) used in the Tunisian folkloric medicine. World $\mathrm{J}$ Microbiol Biotechnol 25: 2227-2238.

21. Han, X., Shen, T., Lou, H. (2007). Dietary polyphenols and their biological significance. Int. J. Mol. Sci. 8, 950-988.

22. Herrlinger KA, Lewis BJ, Lasrado JA, Sanoshy KD, Baldwin JM, Mah E, et al. Acute effects of a proprietary spearmint extract on cognition in healthy men and women. Soc Neurosci 2016; 88(27).

23. http://www.mountainroseherbs.com/spearmint.php

24. Husain A, Janardhanan KK. (1965). Stolon rot of Japanese mint. Curr Sci 34: 156-157.

25. Hussain AI, Anwar F, Nigam PS, Ashraf M, Gilani AH. (2010). "Seasonal variation in content, chemical composition and antimicrobial and cytotoxic activities of essential oils from four Mentha species". Journal of the Science of Food and Agriculture 90: 1827-1836.

26. Igoumenidis PE, Lekka EG, Karathanos VT. (2016). Fortification of white milled rice with phytochemicals during cooking in aqueous extract of Mentha spicata leaves. An adsorption studies. LWT-Food Sci Technol 65: 589-596.

27. Inoue, T., Sugimoto, Y., Masuda, H., Kamei, C. (2002). Antiallergic effect of flavonoid glycosides obtained from Mentha piperita L. Biol. Pharm. Bull. 25 (2), 256-259.

28. Jirovetz L, Buchbauer G, Shahabi M, Ngassoum MB. (2002). Comparative investigations of the essential oil and volatiles of spearmint. Perfume Flavor 27: 16-22.

29. Jonker C, Geerlings MI, Schmand B. (2000). Are memory complaints predictive for dementia? A review of clinical and population-based studies. Int J Geriatr Psychiatry, 15:983-991.

30. Kanatt SR, Chander R, Sharma A. (2007). Antioxidant potential of mint (Mentha spicata L.) in radiation-processed lamb meat. Food Chem 100: 451-458.

31. Kiselova Y, Ivanova D, Chervenkov T, Gerova D, Galunska B. (2006). Correlation between the in vitro antioxidant activity and polyphenol content of aqueous extracts from Bulgarian herbs. Phytother Res 20: 961-965.

32. Kizil S, Hasimi N, Tolan V, Kilinc E, Yuksel U. (2010). Mineral content, essential oil components, and biological activity of two mentha species (M. Piperita L, M. spicata L.). Turk J Field Crops 15: 148-153.

33. Klinkenberg I, Sambeth A, and Blokland A. Acetylcholine and attention. Behav Brain Res 2011; 221:430-442.

34. Kosar, M., Dorman, H.D., Can Baser, K.H., Hiltunen, R. (2004). Screening of free radical scavenging compounds in water extracts of Mentha samples using a postcolumn derivatization method. J. Agric. Food Chem. 52 (16), 5004-5010.

35. Kristin M.N., Kristen D.S., Letizia B., Arianne L.S., Kathleen M.K., Andrea L.L., Michael A.C., Kevin C.M., Daniele D.R., Kelli A.H. (2015). Tolerance, bioavailability, and potential cognitive health implications of a distinct aqueous spearmint extract. Functional Foods in Health and Disease 2015; 5(5):165187. 
36. Kumar P, Mishra S, Malik A, Satya S. (2011). Insecticidal properties of Mentha species: a review. Indus. Crops Prod 34: 802-817.

37. Lawrence BM. (2006). Mint: the genus Mentha. CRC Press.

38. Lawrence, B.M. (2007). Mint. The Genus Mentha. CRC Press Taylor \& Francis Group, New York.

39. LUST J. (1983). The herb book, Banton books ISBN 0-55323827-2.

40. Mata AT, Proença C, Ferreira AR, Serralheiro MLM, Nogueira JMF. (2007). Antioxidant and anti acetylcholinesterase activities of five plants used as Portuguese food spices. Food Chem 103: 778-786.

41. McKay, D.L., and Blumberg, J.B. (2006). A review of the bioactivity and potential health benefits of peppermint tea (Mentha piperita L.). Phytother. Res. 20 (8), 619-633.

42. Nieman KM, Sanoshy KD, Bresciani L, Schild AL, Kelley KM, Lawless AL. (2015). Tolerance, bioavailability, and potential cognitive health implications of a distinct aqueous spearmint extract. Funct Foods Health Dis 2015; 5:165-187.

43. Özer H, Sökmen M, Güllüce M, Adigüzel A, Sahin F. (2007). Chemical composition, antimicrobial and antioxidant activity of the essential oil and methanol extract of Hippomarathrum mirocarpum (Bieb.) from Turkey. J Agric Food Chem 55: 937942.

44. Park KJ, Vohnikova Z, Brod FPR. (2002). Evaluation of drying parameters and desorption isotherms of garden mint leaves (Mentha crispa L.). J Food Eng 51: 193- 199.

45. Paul H. Falcone, Kristin M. Nieman, Aaron. Tribby, Roxanne M. Vogel, Jordan M. Joy, Jordan R. Moona, Chantelle A. Slaytona, Micah M. Henigmana, Joanne A. Lasrado, Brandon J.Lewis , Brenda. Fonsecab, Kelli. Herrlinger. (2018). The attention-enhancing effects of spearmint extract supplementation in healthy men and women: a randomized, double-blind, placebo-controlled, parallel trial.

46. Peter KV. (2006). Handbook of herbs and spices (Vol. 3). The composition of commercially important mints.Mint: Genus Mentha. Taylor \& Francis Group, Boca Raton, FL, pp: 88-89.

47. Ramesh, S.Y., Sandeep, K., and Anupam, D. (2006). Antifungal properties of essential oil of Mentha Spicata L. var. MSS-5. Indian J. Crop Sci. 1 (1-2), 197-200.

48. Sacchetti G, Maietti S, Muzzoli M, Scaglianti M, Manfredin S. (2005). Comparative evaluation of essential oils of different origin as functional antioxidants, antiradicals, and antimicrobials in foods. Food Chemistry 91: 621-632.

49. Samarth RM, Kumar A. (2003). Mentha piperita (Linn.) leaf extract provides protection against radiation-induced chromosomal damage in the bone marrow of mice. Indian J Exp Biol 41: 229-237.

50. Sarter M, Givens B, Bruno JP. (2001). The cognitive neuroscience of sustained attention: where top-down meets bottom-up. Brain Res Rev 2001; 35:146-160.

51. Scherer R, Lemos MF, Lemos MF, Martinelli GC, Martins JDL. (2013). Antioxidant and antibacterial activities and composition of Brazilian spearmint (Mentha spicata L.). Indus. Crops Prod 50: 408-413.

52. Shahbazi Y. (2015). Chemical Composition and In Vitro Antibacterial Activity of Mentha spicata Essential Oil against Common Food-Borne Pathogenic Bacteria. J Pathog 2015: 5.

53. Shen, D., Pan, M.H., Wu, Q.L., Park, C.H., Juliani, H.R., Ho, C.T., and Simon, J.E. (2011). A rapid LC/MS/MS method for the analysis of nonvolatile antiinflammatory agents from Mentha spp. J. Food Sci. 76 (6), C900-C908.

54. Singh R, Shushni MA, Belkheir A. (2015). Antibacterial and antioxidant activities of Mentha piperita L. Arab J Chem 8: 322328.

55. Sulieman AME, Abdelrahman SE, Rahim AMA. (2011). Phytochemical analysis of local Spearmint (Mentha spicata) leaves and detection of the antimicrobial activity of its oil. J Microbiol Res 1: 1-4.

56. Tang, K.S., and Konczak, I., Zhao, J. (2016). Identification and quantification of phenolics in Australian native mint (Mentha australis R. Br.). Food Chem. 192, 698-705.

57. Tetik F, Civelek S, Cakilcioglu U. (2013). Traditional uses of some medicinal plants in Malatya (Turkey). J Ethnopharmacol 146: 331-346.

58. Tognolini M, Barocelli E, Ballabeni V, Bruni R, Bianchi. (2006). Comparative screening of plant essential oils: phenylpropanoid moiety as basic core for antiplatelet activity. Life Sci 78: 1419-1432.

59. Tyagi AK, Malik A. (2011). Antimicrobial potential and chemical composition of Mentha piperita oil in liquid and vapour phase against food spoiling microorganisms. Food Control 22: 1707-1714.

60. Wang H., Provan G.J., and Helliwell, K. (2004). Determination of rosmarinic acid and caffeic acid in aromatic herbs by HPLC. Food Chem. 87 (2), 307-311.

61. Yin G, Li YM, Wei W, Jiang SH, Du WH. Interactions of acetylcholinesterase with salvianolic acid $\mathrm{B}$ and rosmarinic acid from Salvia miltiorhiza water extract investigated by NMR relaxation rate. Chin Chem Lett 2008; 19:747-751.

62. Zheng W., and Wang S.Y. (2001). Antioxidant activity and phenolic compounds in selected herbs. J. Agric. Food Chem. 49 (11), 5165-5170.

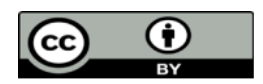

This work is licensed under Creative Commons Attribution 4.0 License
Ready to submit your research? Choose Auctores and benefit from:

$>$ fast, convenient online submission

$>$ rigorous peer review by experienced research in your field

$>$ rapid publication on acceptance

$>$ authors retain copyrights

$>$ unique DOI for all articles

$>$ immediate, unrestricted online access

At Auctores, research is always in progress.

Learn more auctoresonline.org/journals/nutrition-and-food-processing 